\title{
Optimization of Human Interferon $\alpha 2 b$ Soluble Protein Overproduction and Primary Recovery of Its Inclusion Bodies
}

\author{
RATIH ASMANA NINGRUM, DEBBIE SOFIE RETNONINGRUM, \\ YEYET CAHYATI, AND HENI RACHMAWATI* \\ School of Pharmacy, Institut Teknologi Bandung, \\ Jalan Ganesha 10, Bandung 40132, Indonesia
}

\begin{abstract}
The hIFN2b open reading frame has been constructed and overexpressed in Escherichia coli BL21(DE3). The yields of protein purified using nickel column from inclusion bodies (IB) and total soluble proteins were $3.46 \mathrm{mg}$ and $2.57 \mathrm{mg}$ in $1 \mathrm{~L}$ culture, respectively. This research was aimed to obtain optimal condition for high level overproduction of soluble hIFN $\alpha 2 \mathrm{~b}$ as well as primary recovery of hIFN2b from IB. We used two different conditions for obtaining soluble protein, i.e. induction temperatures and inducer concentrations, and three different conditions for inclusion bodies, i.e. centrifugation speeds, washing and solubilizing buffers. Induction using $0.5 \mathrm{mM}$ of isopropyl thiogalactopyranoside at $25^{\circ} \mathrm{C}$ yielded $8.9 \mathrm{mg}$ hIFN2b in $1 \mathrm{~L}$ culture. The best recovery of IB was achieved when $10000 \mathrm{~g}$ was applied for centrifugation, $1 \%$ Triton X-100 in $50 \mathrm{mM}$ Tris $\mathrm{Cl} \mathrm{pH} 8.0$ as washing buffer, and $8 \mathrm{M}$ guanidine $\mathrm{HCl}$ in $50 \mathrm{mM}$ Tris $\mathrm{Cl} \mathrm{pH} 8.0$ containing $800 \mathrm{mM}$ 2-mercaptoethanol as solubilizing buffer were used. At this optimal condition the yield of hIFN2b from IB was $28.85 \mathrm{mg}$ in $1 \mathrm{~L}$ culture. The total recovery of hIFN $\alpha 2$ b at optimal condition was $50 \%$ from IB and $14 \%$ from soluble protein. hIFN2b from IB was refolded by 9 $\mathrm{d}$ dialysis in refolding buffer (0.2 mM EDTA, $0.25 \mathrm{mM}$ ditiothreitol, $50 \mathrm{mM}$ Tris and 0.4 M urea pH 8.0).
\end{abstract}

Key words: human interferon $\alpha 2 \mathrm{~b}$, overproduction, soluble protein, inclusion bodies, protein refolding

Kerangka baca terbuka hIFN2b telah dikonstruksi dan diekspresikan dalam Escherichia coli BL21(DE3) pada penelitian sebelumnya. Jumlah protein yang dimurnikan menggunakan kolom nikel dari badan inklusi (BI) dan protein terlarut total ialah masing-masing 3.46 dan $2.57 \mathrm{mg}$ dalam $1 \mathrm{~L}$ biakan. Penelitian ini ditujukan untuk memperoleh kondisi optimal pada overproduksi hIFNa2b terlarut dan perolehan hIFNa2b dari BI. Dua kondisi yang berbeda digunakan untuk mendapatkan protein terlarut, yaitu suhu dan konsentrasi badan penginduksi, serta tiga kondisi yang berbeda untuk BI, yaitu kecepatan sentrifugasi, dapar pencuci, dan pensolubilisasi. Penggunaan suhu $25^{\circ} \mathrm{C}$ dan isopropil tiogalaktopiranosida $0.5 \mathrm{mM}$ sebagai penginduksi telah menghasilkan hIFN2b sebanyak $8.9 \mathrm{mg}$ dalam $1 \mathrm{~L}$ kultur. Perolehan terbaik dari badan inklusi diperoleh dengan menggunakan kecepatan sentrifugasi $10000 \mathrm{~g}$, dapar pencuci Triton X-100 1\% dalam Tris $\mathrm{Cl} 50$ $\mathrm{mM} \mathrm{pH}$ 8.0, dan dapar pensolubilisasi guanidine $\mathrm{HCl} 8 \mathrm{M}$ yang mengandung 2-merkaptoetanol $800 \mathrm{mM}$ dan Tris $\mathrm{Cl} 50 \mathrm{mM}$ pH 8.0. Dengan menggunakan kondisi optimal dihasilkan hIFN2b dari BI sebanyak $28.8 \mathrm{mg}$ dalam $1 \mathrm{~L}$ biakan. Renaturasi hIFN2b dari BI dilakukan dalam dapar perenaturasi (EDTA $0.2 \mathrm{mM}$, ditiotreitol $0.25 \mathrm{mM}$, Tris $50 \mathrm{mM}$, dan urea $0.4 \mathrm{M} \mathrm{pH} 8.0$ ) selama 9 hari.

Kata kunci: interferon $2 \mathrm{~b}$ manusia, overproduksi, protein terlarut, badan inklusi, pelipatan kembali protein

Interferon (IFN) is a cytokine produced and secreted by almost all eukaryotic cells as a response to viral, bacterial, antigen, or mitogen stimuli. Based on their receptor types on the cell membrane surface, IFN is classified into type I and type II. Type I consists of IFNa, IFN $\beta$, IFNT, and IFN $\omega$. While type II consists of IFNy (Wang et al. 2002; Gao et al. 2004). IFNa has wide range of biological activities ranging as antiproliferation, immunomodulation, and antivirus (Samuel 2001). Human IFN2b (hIFN2b), as a subclass of IFNa, is a glycoprotein consisting of 165 amino acids with size of 19271 Dalton. The molecule's Oglycosylation at threonine position 106 is not important for its biological activity (Nyman et al. 1998). hIFN2b has two disulfide bridges formed by cysteins (between positions 1 and 98, and between 29 and 138). Previous study reported that disruption of disulfide bridges

*Corresponding author: Phone: $+62-22-2504852$ Fax:+62-22-2504852 Email: h_rachmawati@fa.itb.ac.id formed by cystein 1 and 98 resulted in higher antiviral activity (Neves et al. 2004). So far hIFNa2b is used as a therapeutic protein for hepatitis B and hepatitis C treatments, both as a single therapy or in combination with other nucleoside analogs (Jonasch and Haluska 2001). Its use to treat several types of cancer, i.e. multiple myeloma, chronic myeloid leukemia, nonHodgkin's lymphoma, renal cell carcinoma, epidermoid cervical cancer, head and neck tumours, melanoma and medullary thyroid carcinoma, had also been reported as well (Wang et al. 2002).

In vitro DNA manipulation has been applied to express many eukaryotic genes in prokaryotes, such as Escherichia coli. However, the use of E. coli as an expression host often results in the formation of insoluble protein in inclusion bodies (IB). For proteins containing disulfide bridges, IB formation tends to be higher than those without disulfide bridges. In order to recover its activity several procedures including solubilization, refolding, and purification is absolutely 
necessary (Rabhi-Essafi et al. 2007). Two factors that influence IB formation are protein properties (average charge, cysteine and proline contents, hydrophilicity, and total number of residues) and environmental or culture condition (temperature, $\mathrm{pH}$, and nutrient supply) (Fischer and Sumner 1993; Rabhi-Essafi et al. 2007). Several publications have reported cloning and overexpression of hIFN-2b gene in E. coli with various yields (Neves et al. 2004; Srivasta et al. 2005; Valente et al. 2006). In addition, optimization of IB primary recovery of hIFN-2b expressed in E. coli has been reported. The recovery of IB from optimal condition ranged from $61 \%$ to $68 \%$ (Valente et al. 2006).

In our previous work (Retnoningrum et al. 2010), we assembled synthetic open reading frame (ORF) encoding for hIFN-2b using thermodynamically balanced inside out method. The ORF was cloned and overexpressed in $E$. coli BL21(DE3). The recombinant $\mathrm{hIFN}-2 \mathrm{~b}$ was produced as a fusion protein of $37 \mathrm{kDa}$, containing thioredoxin and polihistidine tag at its $\mathrm{N}$ terminus. The protein was confirmed to be hIFN-2b by Nano LC MS/MS resulting $80 \%$ amino acids coverage. Therefore, this research aimed to obtain optimal condition for overproduction of hIFN $\alpha 2 b$ in soluble form and primary recovery of hIFN2b from IB. Optimal condition will be used to obtain highest expression level in the future.

\section{MATERIALS AND METHODS}

Bacterial Strains, Plasmids, and Culture Media. E. coli BL21(DE3) harbouring pET32b-hifna2b recombinant plasmid from previous work was used for gene expression (Retnoningrum et al. 2010).

Overproduction of hIFN-2b. E. coli BL21(DE3) pET32b-ifn $2 b$ overnight culture was added $\left(3 \% \mathrm{v} \mathrm{v}^{-1}\right)$ to $100 \mathrm{~mL}$ of LB broth containing $100 \mu \mathrm{g} \mathrm{mL}^{-1}$ of ampicillin. The culture was incubated for about $1.5 \mathrm{~h}$ in a shaking incubator at $37{ }^{\circ} \mathrm{C} 200 \mathrm{rpm}$. Three final concentrations of IPTG $(0.25,0.5$, and $1.0 \mathrm{mM})$ were each added to midlog phase of cell culture. Incubation was continued for an additional $3 \mathrm{~h}$. Cell pellet was harvested by centrifugation at $5000 \mathrm{~g}$ for $10 \mathrm{~min}$. The cells were resuspended in lysis buffer $(50 \mathrm{mM} \mathrm{NaCl}$ and $1 \mathrm{mM}$ EDTA), the composition that was reported by Valente et al. (2006). The cells were lyzed by sonication at 2.5 Hertz in the presence of $1 \mathrm{mM}$ of phenylmethyl sulphonyl fluoride. To prevent temperature elevation, the cells were sequentially sonicated and cooled on ice for 10 times, each time for $30 \mathrm{~s}$. Soluble recombinant protein was separated from IB by centrifugation at $10000 \mathrm{~g}$. The soluble protein was purified using nickel column according to the manufacturer's protocol (Protino, Germany). The protein isolation and overproduction steps were monitored using $15 \%$ sodium dodecyl sulphate polyacrylamide gel electrophoresis (SDS-PAGE). To determine the yield, protein concentration was measured based on coomassie blue staining using Bradford method with standard concentrations of bovine serum albumin were ranging from 125 to $1000 \mu \mathrm{g} \mathrm{mL}^{-1}$.

Optimization of Inclusion Bodies Primary Recovery. Optimization of inclusion bodies primary recovery referred to condition as reported by Valente et al. (2006) with some modifications. After sonication, IB was separated from soluble protein by centrifugation for $10 \mathrm{~min}$. Five centrifugation speeds $500,1000,2500,5000$, and $10000 \mathrm{~g}$ were tested in this experiment. The cells were washed with washing buffer $(750 \mu \mathrm{L}$ of buffer for each $0.1 \mathrm{~g}$ of pellet), incubated at room temperature for $5 \mathrm{~min}$ and centrifuged at $12000 \mathrm{~g}$ for $5 \mathrm{~min}$. The washing step was repeated to remove impurities. Two washing buffers were studied, i.e. buffer A $(50 \mathrm{mM}$ Tris $\mathrm{Cl}$ pH 8 containing $1 \%$ Triton X-100) and buffer B (lysis buffer containing $0.5 \%$ Triton $\mathrm{X}-100 \mathrm{pH}$ 7.2). The washed pellet was resuspended in solubilizing buffer $(750 \mu \mathrm{L}$ of buffer for each $0.1 \mathrm{~g}$ of pellet) for $30 \mathrm{~min}$ at room temperature. Two solubilizing buffers were tested, guanidine $\mathrm{HCl}(\mathrm{GdnHCl})$ buffer consisted of $6 \mathrm{M}$ $\mathrm{GdnHCl}$ in $50 \mathrm{mM}$ Tris- $\mathrm{HCl} \mathrm{pH} 8$ containing either 2mercaptoethanol (2-ME) or dithiotreitol (DTT). To observe the effect of reducing agents, various concentrations of 2-ME $(100,200,400,650$, and 800 $\mathrm{mM})$ and DTT $(20,50,100,200$, and $300 \mathrm{mM})$ were tested. Subsequently, solubilized pellet was centrifugated at $15000 \mathrm{~g}$ for $15 \mathrm{~min}$ and $4^{\circ} \mathrm{C}$ to separate hIFN $\alpha 2 b$ and unsolubilized material. hIFN $\alpha 2 b$ from IB was characterized using SDS-PAGE and its concentration was measured.

Protein Refolding. Dialysis was perfomed to refold hIFN $\alpha 2 b$ from IB. Two steps were applied, first step to remove denaturant using denaturing removal buffer and the second step to renaturate hIFNa2b from IB using refolding buffer (Valente et al. 2006). To remove the denaturant, $0.6 \mathrm{mg}$ of IB was dialyzed overnight in the cellulose ester membrane (Spectra/Por ${ }^{\circledR}$ CE, $1 \mathrm{~mL}$ volume capacity, MWCO $1000)$ against $250 \mathrm{~mL}$ denaturing removal buffer $(0.2$ mM EDTA in $50 \mathrm{mM}$ Tris, pH8.0) at $4{ }^{\circ} \mathrm{C}$ with gentle agitation. To renaturate the hIFN $\alpha 2 b$ from IB, the hIFNa2b was dialyzed in $250 \mathrm{~mL}$ refolding buffer (0.4 M urea, $0.2 \mathrm{mM}$ EDTA, $0.25 \mathrm{mM}$ DTT in $50 \mathrm{mM}$ Tris, $\mathrm{pH}$ 8.0) for $9 \mathrm{~d}$ with buffer changes every 
$2 \mathrm{~d}$. To monitor the renaturation process, refolded hIFNa2b was analyzed using non reducing SDSPAGE.

\section{RESULTS}

Overproduction of hIFN-2b. The expression profile of soluble hIFN2b showed that the best expression level was achieved at $25{ }^{\circ} \mathrm{C}$ with $0.5 \mathrm{mM}$ IPTG induction (Fig 1). The purity of hIFN2b after purification using nickel affinity chromatography was analyzed using $15 \%$ polyacrylamide gel as shown in

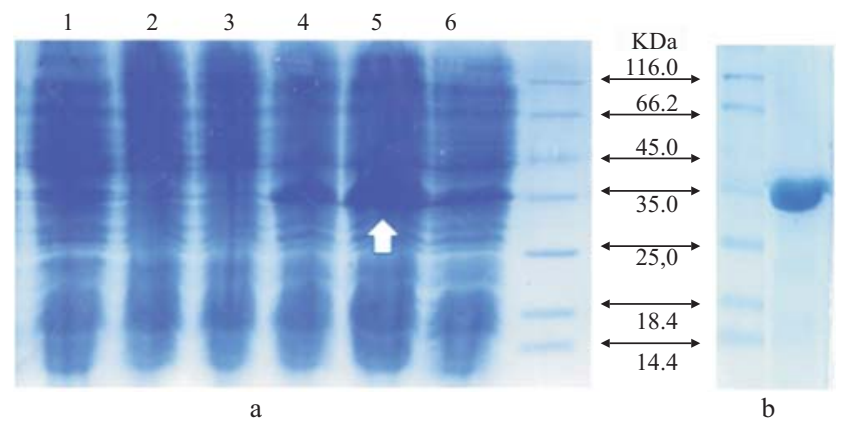

Fig 1 SDS-PAGE of human interferon $2 b$ (hIFN2b) soluble protein. a, Lanes 1-3: total soluble protein produced at $37^{\circ} \mathrm{C}$ with $0.25,0.5$, and $1.0 \mathrm{mM}$ of IPTG. Lanes 4-6: total soluble protein produced at 25 ${ }^{\circ} \mathrm{C}$ with $0.25,0.5$, and $1.0 \mathrm{mM}$ of IPTG. b, Purified hIFN2b soluble protein obtained from optimal condition of overproduction (at $25{ }^{\circ} \mathrm{C}$ with $0.5 \mathrm{mM}$ IPTG).

Fig 1b. Under optimal overproduction condition, the yield of purified hIFN2b was $8.9 \mathrm{mg}$ protein in $1 \mathrm{~L}$ culture. The total recovery of purified hIFN2b was $14 \%$ from total soluble protein.

Optimization of IB Primary Recovery. The solubilization step showed minor impurities in all centrifugation speeds used (Fig 2a). The highest amount of hIFN $\alpha 2 \mathrm{~b}$ from IB was achieved at $10000 \mathrm{~g}$ (Fig 2b). We studied two washing buffers to compare its ability to remove impurities. The impurity profiles of the two buffers looked the same (Fig 3a) but buffer A showed higher IB recovery than buffer B (Fig $3 b$ ).

We used $\mathrm{GdnHCl}$ buffer containing various concentration of 2-ME or DTT in solubilization step. By this mean the impurity profiles did not differ (Fig 4a and b). However, higher IB recovery was achieved when highest concentration of 2-ME was used (Fig 4d). Under this optimal condition the hIFN $22 \mathrm{~b}$ from IB that can be recovered was $28.85 \mathrm{mg}$ $\mathrm{L}^{-1}(50 \%)$, hence made up $64 \%$ total yield of hIFN $\alpha 2 \mathrm{~b}$ protein (14\% from soluble protein and $50 \%$ from IB).

Non-reducing SDS-PAGE was used to check the renaturation result. This method can distinguish protein electrophoretic mobility based on its disulfide bond numbers. One upper band (Fig 5 lane 2) had the same size with solubilized IB and reduced soluble
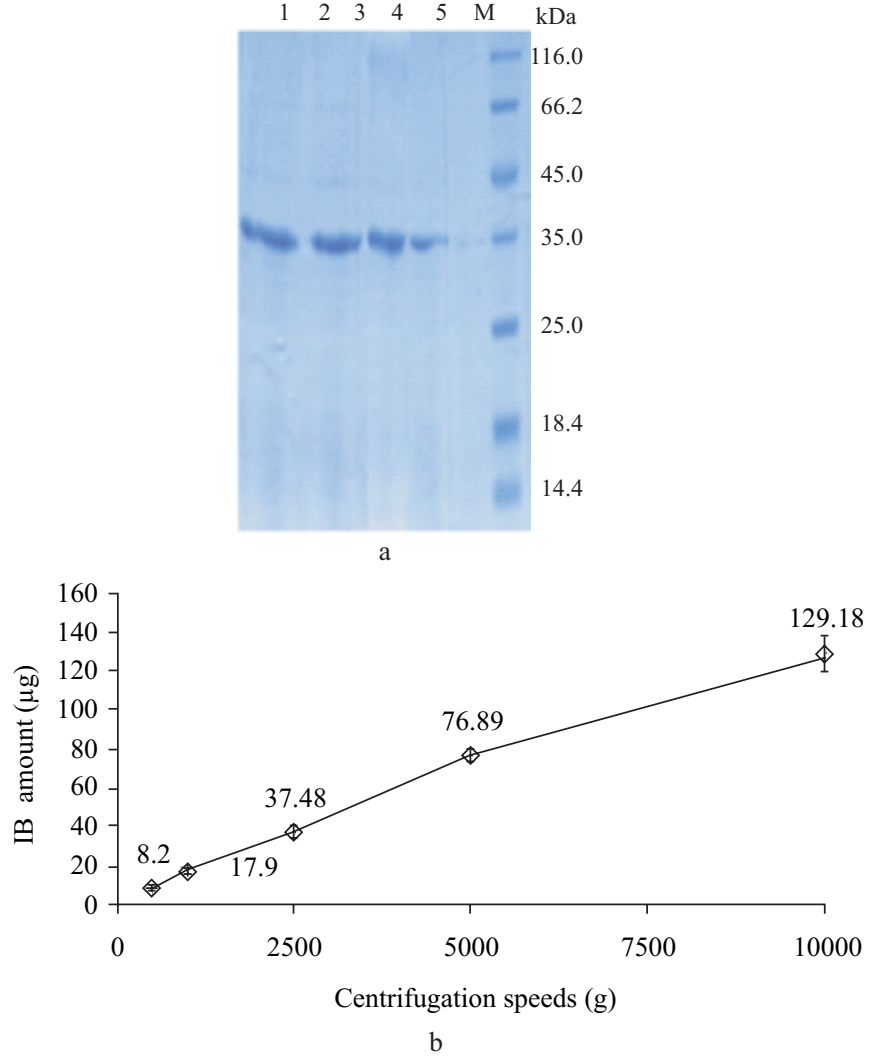

Fig 2 The effect of centrifugation speeds on human Interferon $2 b$ (hIFN2b) inclusion bodies (IB) yield. a, Lanes 1-5: IB sedimented at $10000 ; 5000 ; 2500 ; 1000$; and $500 \mathrm{~g}$. Pellet weight was $0.1 \mathrm{~g}$ and loaded volume was $5 \mu \mathrm{L}$. b, Amount of IB with different centrifugation speed.
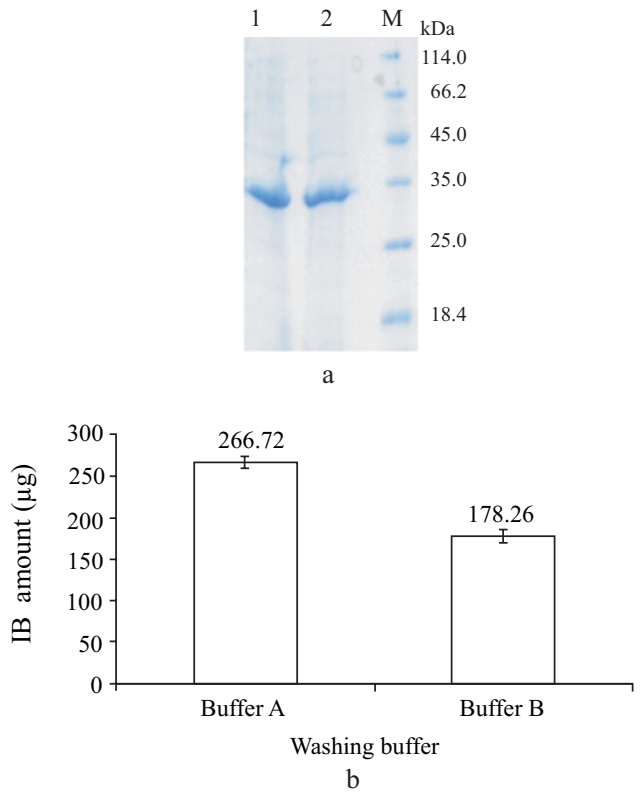

Fig 3 The effect of washing buffer on human interferon 2b (hIFN2b) inclusion bodies (IB) yield. a, Lane 1: IB washed with buffer A (50 mM Tris $\mathrm{Cl} \mathrm{pH} 8$ containing 1\% Triton X-100); lane 2: IB washed with buffer $\mathrm{B}(50 \mathrm{mM} \mathrm{NaCl}$ and $1 \mathrm{mM}$ EDTA containing $0.5 \%$ Triton X-100 pH 7.2). Pellet weight was $0.1 \mathrm{~g}$ and loaded volume was $5 \mu \mathrm{L}$. b, Amount of IB measured using Bradford method in different buffer.

protein (Fig 5 lane 1 and 3) and lower band had the same size with unreduced soluble protein (Fig 5 lane 4). This means that hIFN $\alpha 2 b$ from IB was not totally 

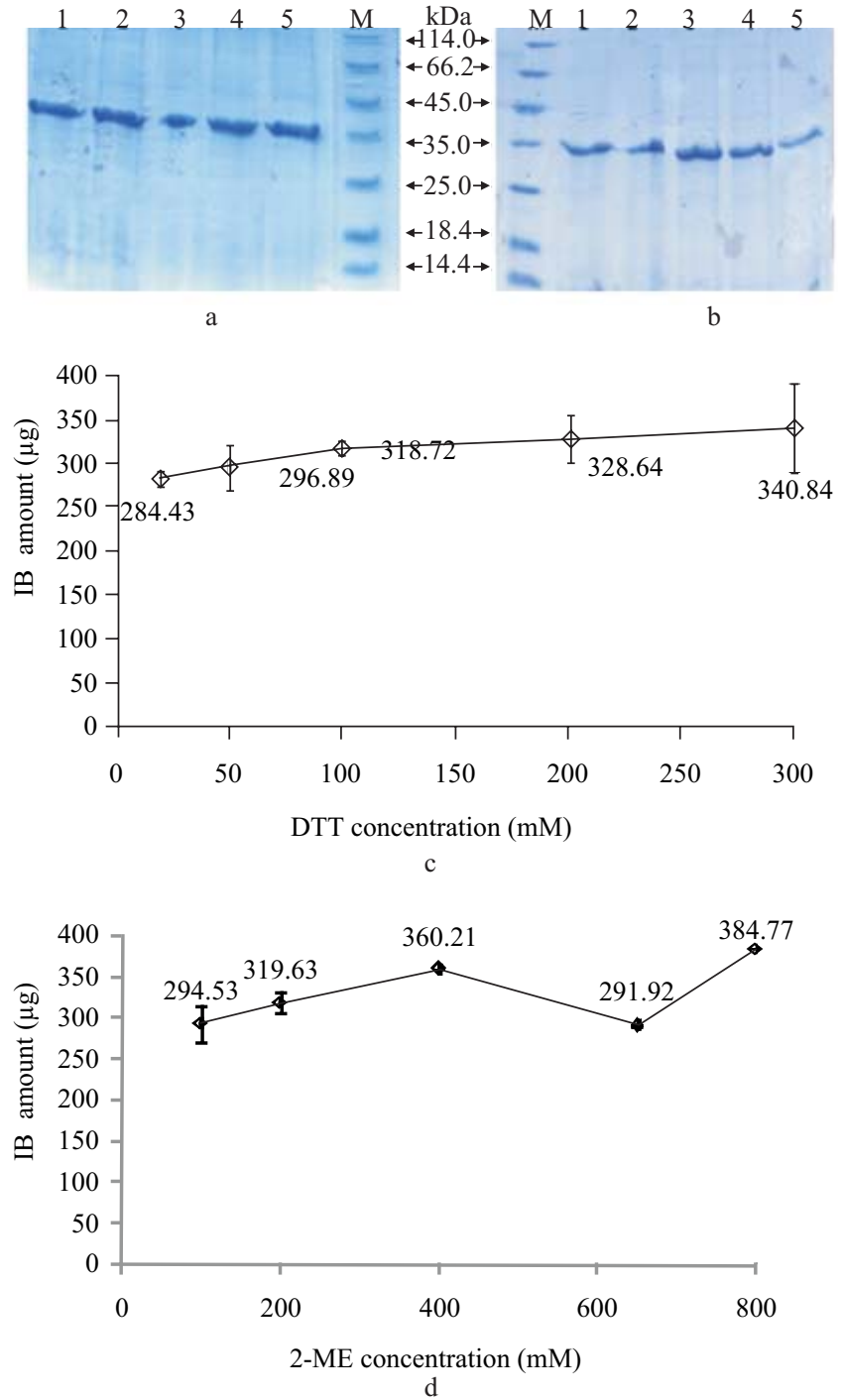

Fig 4 The effect of dithiotreitol and 2-merchapethanol concentrations on the solubilization of human interferon $2 \mathrm{~b}$ (hIFN2b) inclusion bodies (IB) yield. a, Lanes 1-5: solubilized IB with $\mathrm{GdnHCl}$ containing 20, $50,100,200$, and $300 \mathrm{mM}$ DTT. b, The effect of 2-merchapethanol on the solubilization of hIFN2b IB. Lanes 1-5: solubilized IB with $\mathrm{GdnHCl}$ containing $100,200,400,650$, and $800 \mathrm{mM} \mathrm{2-}$ merchapethanol (2-ME). The pellet weight was $0.1 \mathrm{~g}$ and sample volume loaded was $5 \mu \mathrm{L}$. c, IB amount measured by Bradford method in solubilizing buffer containing various concentration of DTT. d, IB amount measured by Bradford method in solubilizing buffer containing various concentration of 2-ME.

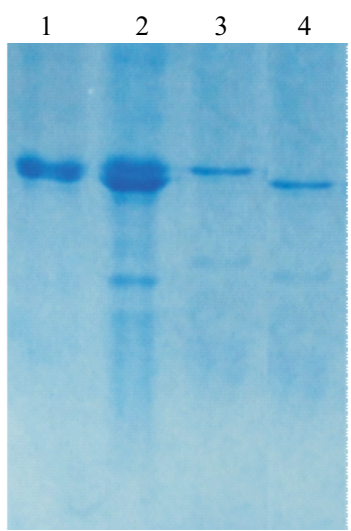

Fig 5 Non-reducing SDS-PAGE of refolded human interferon $2 \mathrm{~b}$ (hIFN2b). Lane 1: solubilized inclusion bodies; 2: refolded hIFN2b ; 3: reduced soluble hIFN2b; 4 : unreduced soluble hIFN2b. refolded. Only about $50 \%$ of hIFN $\alpha 2 \mathrm{~b}$ was refolded and formed disulfide bridges.

\section{DISCUSSION}

Several approaches have been reported to improve the solubility of recombinant hIFN2b including using different expression systems (using Streptococcus lividans, Pichia pastoris, Bacillus subtilis, murine myeloma cell, and baculovirus) and different affinity tags (thioredoxin or gluthatione $\mathrm{S}$ transferase) (Fischer and Sumner 1993). The purification of soluble hIFN2b is more cost effective and less time consuming over refolding and purification from IB. Hence, optimizing production step of recombinant hIFN2b is the most reasonable alternative to reduce IB formation. Previously, we tried to improve hIFN2b solubility by using low copy number plasmid (pET32b) and constructing the hIFN2b fusion protein containing thioredoxin tag. We observed that environmental factors, i.e temperature and IPTG concentration, affected the yield. Current results confirmed that the best expression level was achieved at $25{ }^{\circ} \mathrm{C}$ with 0.5 mM IPTG. Nevertheless, at $37^{\circ} \mathrm{C}$, soluble protein was not obtained when induction was done using 0.25 and $0.5 \mathrm{mM}$ IPTG. This might be due to high level of IB formation. Only when induction was performed using $1.0 \mathrm{mM}$ IPTG soluble protein produced at low level. The result indicates that lowering temperature to $25^{\circ} \mathrm{C}$ whilst still using $0.5 \mathrm{mM}$ IPTG can decrease protein synthesis, therefore, increasing the formation of soluble hIFN2b. Our result is comparable with previous work showing the overproduction of gluthatione $\mathrm{S}$ transferase hIFN2b fusion protein at 25 ${ }^{\circ} \mathrm{C}$ with $0.5 \mathrm{mM}$ IPTG and GFP CheY fusion protein at $25{ }^{\circ} \mathrm{C}$ with $8 \mu \mathrm{M}$ IPTG (Rabhi-Essafi et al. 2007; Sevastsyanovich et al. 2009). However, Cirkovas and Serekaite (2010) reported that overproduction conducted under low temperature $20{ }^{\circ} \mathrm{C}$ improved the solubility of mink growth hormone. In this study, it was demonstrated that simultaneous decrease IPTG concentration into micromolar range did not reinforce the effect of temperature.

The centrifugation speeds at 5000 to $20000 \mathrm{~g}$ commonly used to separate IB from homogenate (Fischer and Sumner 1993). Since the high speed can lead to co-sedimentation of $E$. coli proteins, hence increasing the impurities, we studied various centrifugation speeds (500 to $10000 \mathrm{~g}$ ) to obtain the highest hIFN $\alpha 2 b$ recovery with the lowest impurities. We observed that the impuritiy profiles from each speed did not demonstrate significantly different and 
the highest amount of hIFN $\alpha 2 b$ from IB was obtained at $10000 \mathrm{~g}$. Lowering centrifugation speeds did not lead to high hIFN $\alpha 2 b$ recovery and did not have any effect on eliminating impurities. Valente et al. (2006) reported that at least $5000 \mathrm{~g}$ was needed to recover more than $93 \%$ of hIFN $\alpha 2 b$ from IB but increasing the speed tend to give higher impurities.

IB may contain protein impurities originated from E. coli such as RNA polymerase, outer membrane proteins, or enzymes. Membrane proteins or kanamycin phosphotransferase are soluble impurities. Other IB impurities were washed using buffer containing Triton X-100, sucrose or urea. Triton X-100 that is normally used at concentrations ranging from $0.5 \%$ to $5 \%$ (Fischer and Sumner 1993 ). We observed that varying concentrations of Triton $(0.5 \%$ to $1 \%)$ to remove the impurities did not affect hIFN $\alpha 2 b$ purity. The higher recovery achieved by buffer A might be due to higher $\mathrm{pH}$ (washing condition at $\mathrm{pH} 8.0$ on buffer $\mathrm{A}$ comparing to at $\mathrm{pH} 7.2$ on buffer $\mathrm{B}$ ) that stabilized the hIFNa2b in washing step. Valente et al. (2006) compared two washing buffer, i.e. $20 \mathrm{mM}$ Tris in 50 mM EDTA pH 8.0 and $50 \mathrm{mM}$ Tris-Cl containing 1\% Triton $\mathrm{pH}$ 8. Although the latter buffer resulted in higher purity of IFNa2b, it did not have significant effects on hIFNa2b recovery.

Generally, there are two denaturants used to break existing intramolecular and intermolecular disulfide bonds i.e. urea and $\mathrm{GdnHCl}$. It has been proven that urea combined with DTT is not good for IFN $\alpha 2 b$ IB solubilization (Valente et al. 2006). We examined $\mathrm{GdnHCl}$ buffer containing various concentration of 2ME or DTT as reducing agents. Higher amount of reducing agents reported might lead to cosolubilization of E. coli protein (Valente et al. 2006), however current results showed no difference in impurity profiles of each DTT and 2-ME concentration. Higher hIFNa $2 \mathrm{~b}$ recovery was achieved when the highest concentration $(800 \mathrm{mM})$ of 2-ME was applied. So far, the highest concentration of 2-ME that ever used is $500 \mathrm{mM}$ (Fischer and Sumner 1993). However, there is no good explanation of why using $650 \mathrm{mM}$ of 2-ME resulted in lowest recovery. The total yield of hIFN $\alpha 2 \mathrm{~b}$ protein was $64 \%$, which is higher than previous study reported by Srivasta et $a l$. (2005) and Valente et al. (2006).

Renaturation step after IB solubilization is required to obtain native conformation and to catalyze disulfide bond formation. The denaturants must be removed and IB must be renaturated in oxidizing buffer (Fischer and Sumner 1993). In this study, we used buffer containing Tris and EDTA pH 8.0 to remove denaturant and oxidizing buffer containing urea, DTT, and EDTA $\mathrm{pH}$ 8.0. hIFN $\alpha 2 \mathrm{~b}$ protein was renatured in refolding buffer for 9 days based on previous publication report (Valente et al. 2006). The refolded hIFNa2b protein profile on native gel showed two different bands. The lower band that has same size with the non-reduced soluble protein should correspond to biologically active hIFN $\alpha 2$ b. So it seems that only about $50 \%$ of hIFN $\alpha 2 b$ that could be successfully refolded, so further study is still needed to increase the refolding result. Valente et al. (2006) reported three different bands after $9 \mathrm{~d}$ renaturation. We suggest that thioredoxin tag in the hIFNa2b facilitates the disulfide bridge formation, although Sachdev and Chirgwin (1998) reported that the MBP and thioredoxin fusions of pepsinogen expressed in E. coli did not necessarily facilitate native refolding, but enhanced the recovery of soluble protein.

To conclude, the optimal condition to obtain hIFN $\alpha 2 b$ soluble protein and primary recovery of its inclusion bodies has been established yielding $8.9 \mathrm{mg}$ protein of soluble protein with $14 \%$ recovery and 28.85 mg of IB with $50 \%$ recovery from $1 \mathrm{~L}$ culture.

\section{ACKNOWLEDGEMENTS}

This research was funded by Riset Unggulan Institut Teknologi Bandung 2010 granted to Heni Rachmawati.

\section{REFERENCES}

Cirkovas A, Serekaite J. 2010. Increase in the solubility of recombinant Mink growth hormone at low cultivation temperature of Escherichia coli. Biotechnol Biotechnol Equip. 24(4):2169-2171

Fischer B, Sumner I. 1993. Isolation, renaturation, and formation of disulfide bonds of eukaryotic proteins expressed in Escherichia coli as inclusion bodies. Biotechnol Bioeng. 41(1):3-13. doi:10.1002/bit. 260410103.

Gao B, Hong F, Radaeva S. 2004. Host factors and failure of interferon $\alpha$ treatment in hepatitis C virus. Hepatology. 39(4):880-890. doi:10.1002/hep.20139.

Jonasch E, Haluska FG. 2001. Interferon in oncological practice: review of interferon biology, clinical applications, and toxicities. Oncologist. 6(1):34-55.

Neves FO, Ho PL, Raw I, Pereira CA, Moreira C, Nascimento AL. 2004. Overexpression of a synthetic gene encoding human alpha interferon in Escherichia coli. Protein Expr Purif. 35(2): 353-359. doi:10.1016/j. pep.2004.02.005.

Nyman TA, Kalkkinen N, Tolo H, Helin J. 1998. Structural characterization of N-linked and O-linked oligosaccharides derived from interferon$\alpha 2 \mathrm{~b}$ and interferon- $\alpha 14 \mathrm{c}$ produced by Sendai-virus-induced human peripheral blood leucocytes. Eur J Biochem. 253(2):485-93. doi:10.1046/j.1432-1327.1998.2530485.x.

Rabhi-Essafi I, Sadok A, Khalaf N, Fathallah DM. 2007. A strategy for high-level expression of soluble and functional human interferon $\alpha$ as a GST-fusion protein in E. coli. Protein Eng Des Sel. 20(5):201-209. doi:10.1093/protein/gzm012.

Retnoningrum DS, Ningrum RA, Kurniawan YN, Indrayati AI, Rachmawati H. 2010. Construction of synthetic open reading frame encoding human interferon alpha2b for high expression in Escherichia coli and 
characterization of its gene product. J Biotechnol. 145(2):193-198. doi:10.1016/j.jbiotec.2009.11.008.

Sachdev D, Chirgwin JM. 1998. Solubility of proteins isolated from inclusion bodies is enhanced by fusion to maltose-binding protein or thioredoxin. Protein Expr Purif. 12(1):122-132. doi:10.1006/prep. 1997.0826.

Samuel, CE. 2001. Antiviral actions of interferons. Clin Microbiol Rev. 14(4):778-809. doi: 10.1128/CMR.14.4.778-809.2001.

Sevastsyanovich Y, Alfasi S, Overton T, Hall R, Jones J, Hewitt C, Cole J. 2009. Exploitation of GFP fusion proteins and stress avoidance as a generic strategy for the production of high quality of recombinant protein. FEMS Microbiol Lett. 299:86-94. doi:10.1111/j.15746968.2009.01738.x.
Srivasta P, Bhattacharaya P, Pandey G, Mukherjee KJ. 2005 Overexpression and purification of recombinant human interferon alpha2b in Escherichia coli. Protein Expr Purif. 41(2):313-322. doi:10.1016/j.pep.2004.12.018.

Valente CA, Monteiro GA, Cabral JMS, Fevereiro M, Prazeres DMF. 2006. Optimization of the primary recovery of human interferon $2 b$ from Escherichia coli inclusion bodies. Protein Expr Purif. 45(1): 226-234. doi:10.1016/j.pep.2005.06.014.

Wang YS, Youngster S, Grace M, Bausch J, Bordens R, Wyss DS. 2002. Structural and biological characterization of pegylated recombinant interferon alpha-2b and its therapeutic implications. Adv Drug Deliver Rev. 54(4):547-570. doi:10.1016/S0169-409X(02) 00027-3. 